\title{
СТАНОВЛЕННЯ ЦІННІСНИХ ОРІЕНТАЦІЙ ДІТЕЙ ДОШКІЛЬНОГО ТА МОЛОДШОГО ШКІЛЬНОГО ВІКУ В ІГРОВІЙ ТА НАВЧАЛЬНІЙ ДІЯЛЬНОСТІ В ОСВІТНІЙ СИСТЕМІ «РАДІСТЬ РОЗВИТКУ»
}

\author{
Наукова доповідь на засіданні Президії НАПН України 20 лютого 2020 р.
}

https://doi.org/10.37472/2707-305X-2020-2-1-2-1

\section{ПІРОЖЕНКО}

Тамара Олександрівна доктор психологічних наук, професор, член-кореспондент НАПН України, завідувач лабораторії психології дошкільника Інституту психології імені Г.С. Костюка Національної академії педагогічних наук України, м. Київ, Україна

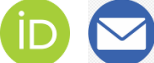

\section{ХАРТМАН Олена Юріївна} кандидат психологічних наук, старший науковий співробітник лабораторії психології дошкільника Iнституту психології імені Г.С. Костюка Національної академії педагогічних наук України, м. Київ, Україна

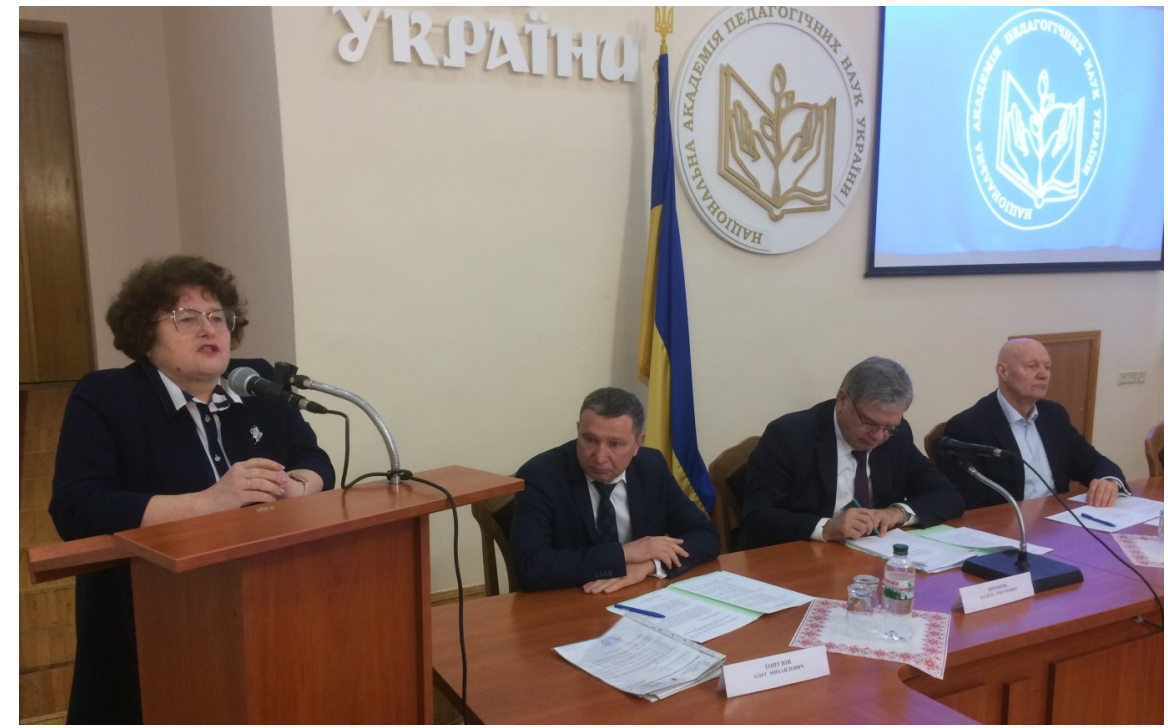

Анотація. У доповіді висвітлено впровадження технології психологопедагогічного проєктування взаємодії дорослого з дитиною «Радість розвитку» у рамках дослідно-експериментальної роботи всеукраїнського рівня «Психолого-педагогічні умови становлення ціннісних орієнтацій dimей в ігровій та навчальній діяльності освітньої системи «Радість розвитку». Описано концептуальні ідеї та завдання дослідження. Центральною і головною ідеєю у впровадженні освітньої системи «Радість розвитку» $\epsilon$ твердження, що життєорганізація ігрової та навчальної діяльності дитини від 2 до 12 років у межах тематичного циклу дає змогу реалізувати психолого-педагогічні умови свободи й прийняття дитиною цінностей, які є механізмом активності, творчої діяльнісної самореалізації та самопрезентації. Виокремлено не тільки зовнішні (соціально-педагогічні), а й внутрішні (психологічні) фактори впливу на прочес прийняття дитиною соціально значущих цінностей. Наведено поточні результати науково-дослідної роботи. Наголошено на високому ступені невизначеності, варіативності, змінюваності розвивальних умов і необхідності визначення балансу методичних прийомів, методів, форм роботи з дітьми дошкільного та молодшого шкільного віку.

Ключові слова: ціннісні орієнтації; освітня система «Радість розвитку»; тематичний цикл; психологія розвитку дитини; субкультура дитинства.

Суттю освітнього процесу на базі методологічних позицій розвивальної технології «Радість розвитку» $€$ створення максимально широкої палітри потенційних освітніх напрямів розвитку на противагу 
єдиній універсальній освітній стратегії. Стрижнева увага в освітньому процесі приділяється зростанню та закріпленню в структурі особистісних якостей людини психологічних надбань, пов'язаних із творчим рівнем будь-якої діяльності.

Теоретико-методологічну основу дослідноекспериментальної роботи «Психологопедагогічні умови становлення ціннісних орієнтацій дітей в ігровій та навчальній діяльності освітньої системи «Радість розвитку» становили: системно-діяльнісна парадигма в дослідженні психіки (О.Г. Асмолов, Г.С. Костюк, О.М. Леонтьєв, С.Д. Максименко), концепція «Генетичні основи становлення та самореалізації особистості» (С.Д. Максименко), науково-психологічні уявлення про закономірності розвитку діяльнісної сфери дітей дошкільного та молодшого шкільного віку (Р.С. Буре, В.В. Давидов, О.В. Запорожець, С.Д. Максименко, С.Л. Рубінштейн, Д.Б. Ельконін), комунікативний підхід у вирішенні питань розвитку активного мовлення дошкільників (М.І. Лісіна, Т.О. Піроженко, А.Г. Руська).

Можна стверджувати, що експериментальна робота «Психолого-педагогічні умови становлення ціннісних орієнтацій дітей в ігровій та навчальній діяльності освітньої системи «Радість розвитку» спирається на глибоке наукове підґрунтя проблеми особистісного зростання дитини дошкільного віку. Концептуально підтверджений напрям дитячої психології (психології комунікативно-мовленнєвого розвитку дитини дошкільного віку (Т.О. Піроженко) та інтеграційний підхід до оцінки особистісної активності та самореалізації дитини через генезис мовлення, який характери- зує мовленнєвий розвиток дитини дошкільного віку в єдності психологічних досягнень у поведінці, свідомості, особистості загалом, знайшов втілення у галузі педагогічної психології. Його втілення відбувається через розроблення та впровадження авторської технології психологопедагогічного проєктування взаємодії дорослого з дитиною, спрямованої на розвиток здібностей дітей (освітня технологія «Радість розвитку»). Технологія «Радість розвитку» (свідоцтво про реєстрацію авторського права №№ 33342 та 33343) органічно пов'язана зі змістом сучасної дошкільної світи, визначеної в її Базовому компоненті, співвідноситься з усіма чинними програмами системи дошкільної освіти, затвердженими Міністерством освіти і науки України. Впровадження освітньої технології психологопедагогічного проєктування взаємодії дорослого з дитиною «Радість розвитку» було реалізовано у 11 областях України: Київській, Житомирській, Сумській, Волинській, Вінницькій, Хмельницькій, Миколаївській, Чернігівській, Донецькій, Запорізькій, Івано-Франківській. Творча група науковців Інституту психології імені Г.С. Костюка НАПН України - Т.О.Піроженко, С.О. Ладивір, О.Ю.Хартман - стала лауреатом Державної премії України в галузі освіти 2018 року (номінація дошкільна і позашкільна освіта) за Комплексну науково-прикладну роботу «Освітня технологія «Радість розвитку» - партнерська взаємодія дорослих та дітей» (Указ Президента України від 4 жовтня 2018 р. № 301).

Реалізація експериментальної роботи проєкту «Становлення ціннісних орієнтацій дітей дошкіль-

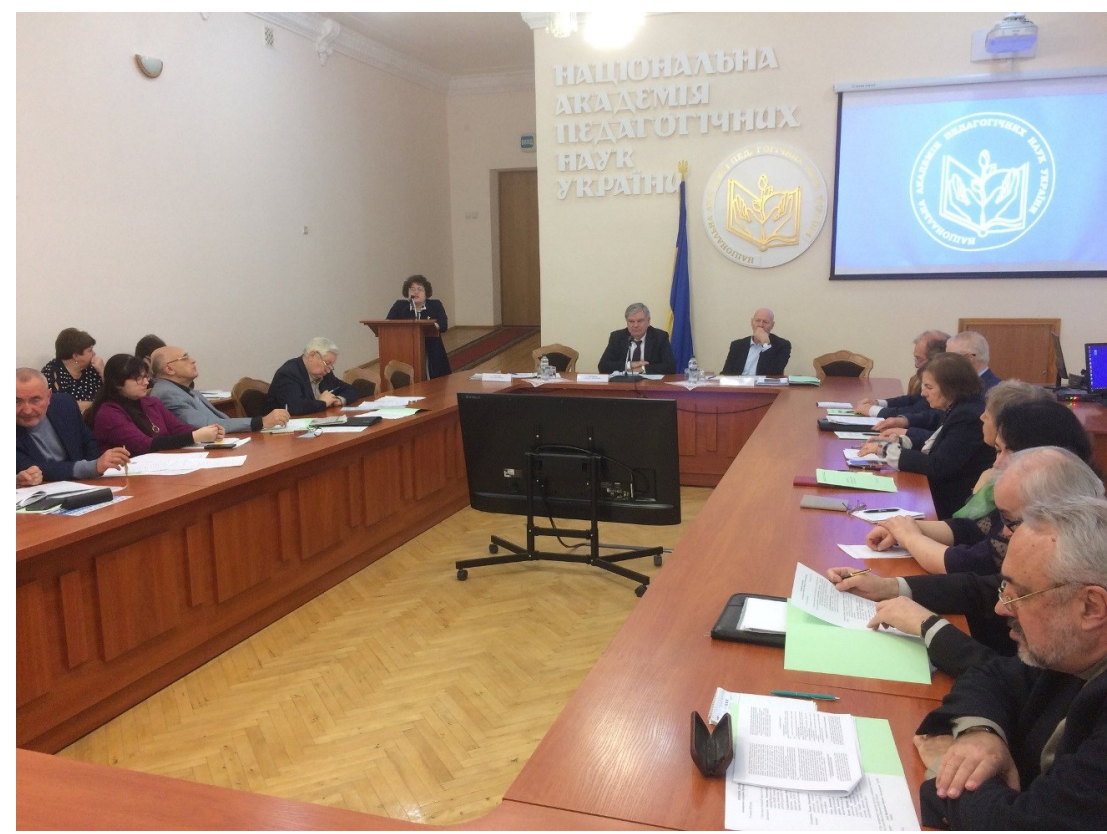

ного та молодшого шкільного віку в ігровій та навчальній діяльності в освітній системі «Радість розвитку» спиралась на теоретичні напрацювання та обґрунтовані позиції працівників лабораторії психології дошкільника Інституту психології імені Г.С. Костюка НАПН України 3 проблеми «Психологопедагогічні чинники прийняття дитиною старшого дошкільного віку соціально значущих цінностей» (науковий керівник Т.О. Піроженко). Наукові засади вивчення ціннісних орієнтацій дітей дошкільного віку представлено співробітниками лаборато- 


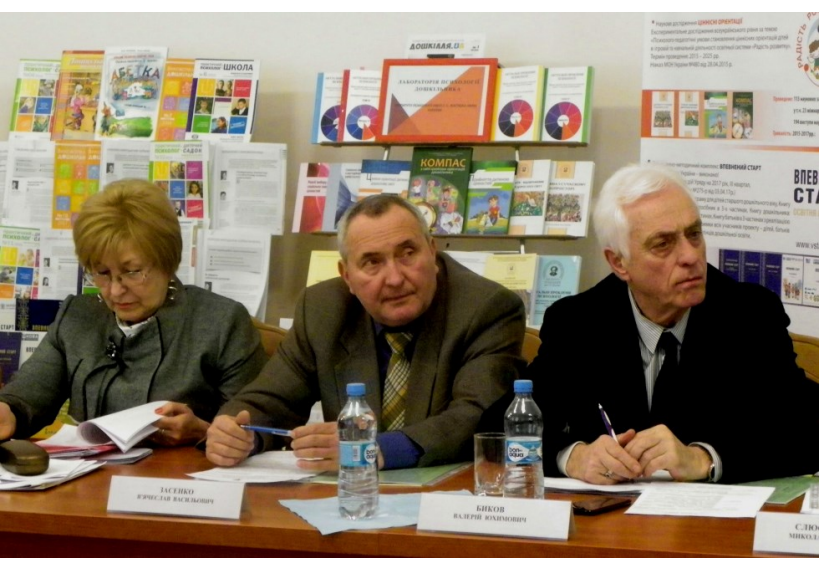

рії психології дошкільника Інституту психології імені Г.С. Костюка НАПН України в численних публікаціях, втілено в освітній практиці. У період 2010-2019 рр. опубліковано більш ніж 160 праць, з них 25 методичних посібників, програм і методичних рекомендацій.

Освітній простір, у якому відбувається становлення особистості, утворюється змістовним навантаженням різного рівня інтеграції і складності. Основним у цьому процесі $є$ ціннісне ставлення особистості до змісту та діяльності, в якій реалізується пошук смислів. Розв'язати проблему узгодження виховних впливів із запитом головного замовника освіти - дитини, можна за рахунок активізації діяльності, притаманної кожному віковому періоду, та дотримання принців організації діяльності. Провідними принципами $є$ : гуманізація освіти, врахування індивідуальних і типологічних особливостей особистості, наступності, поваги до особистості, діяльнісний принцип тощо. Важливими для реалізації системи «Радість розвитку» є принципи пріоритету особистості (довіра, захист, підтримка) та роботи в команді (узгодженість дій, довіра до партнера, здорова конкуренція тощо), які втілюють сутнісні тенденції цієї освітньої системи. В основу побудови теоретичних і практичних настанов експериментального дослідження покладено ідею визначення підґрунтя діяльнісної самопрезентації особистості через різні специфічні для кожного вікового періоду види діяльності в освітньому просторі з виокремленням системоутворювальної складової - самореалізації. Остання розглядається як реалізація свободи й відповідальності людини за себе і свої стосунки із зовнішнім світом.

Саме визначення, підтримка та розвиток психологічних особливостей самореалізації особистості в освітньому просторі через поєднання ії ціннісно-смислових, мотиваційно-

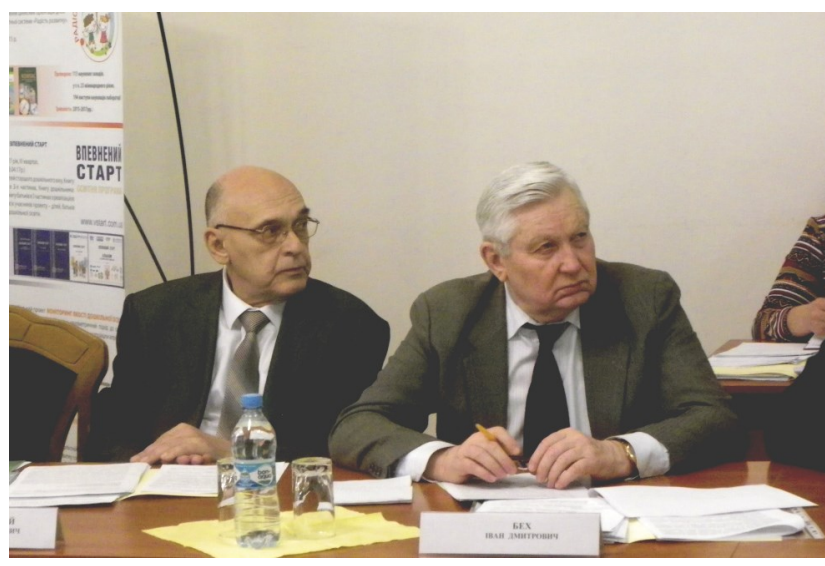

потребових, інструментальних, емоційновольових і рефлексивно-оцінних характеристик забезпечує процес організації життєдіяльності дітей в освітній системі «Радість розвитку».

Можна сказати, що лейтмотивом усіх психолого-педагогічних дій дорослого є: гармонізація та усвідомлення дитиною мотиваційних рушійних сил (що я ХОЧУ!); інструментальних можливостей, тобто знань, умінь і навичок (що я МОЖУ!); регуляції діяльності та поведінки на репродуктивному та творчому рівні (що я БУДУ! здійснювати). Так, діючи разом, дорослі актуалізують здатність дітей мріяти (розвиваючи найістотніший для періоду дошкільного дитинства когнітивний процес - уяву), ставити цілі з досягнення спільного результату, навчатися способам розподілення пізнавальних дій і досягнення мети, вправлятися у формуванні навичок у різних видах діяльності, i, головне, створюють можливості для набуття досвіду втілення мрії (образу результату) у творчій діяльності.

Єдність і взаємозв'язок усіх психологічних новоутворень упродовж вікового зростання дитини від раннього до підліткового віку дає змогу не лише окреслити шляхи самореалізації як системного психологічного утворення, а й розкрити істотні міжрівневі зв'язки психологічного зростання з процесом становлення ціннісних орієнтацій особистості.

Важливість наукового аналізу цього питання посилюється запитом сучасного суспільства на підтримку становлення людини, яка має чітку систему поглядів, що надають життю осмисленості, ясності, розуміння мети особистісної активності, почуття власної гідності, почуття значущості своїх виборів, а це загалом характеризує сформованість життєвої компетентності. У цілому актуальність дослідження визначається потребою збалансування зусиль дорослих у забезпеченні повноцінного психічного розвитку дітей і 
потребою підвищення якості розвитку дитинства на основі базових духовних засад життєдіяльності людини у соціумі. Актуальність посилюється значущістю становлення психологічних надбань дитини, які закріплюються у структурі особистості в період проживання старшим дошкільником вікової кризи 6(7) років. Основним надбанням цього періоду $є$ становлення механізмів свідомої регуляції власної поведінки, що зумовлює можливість вибору та прийняття дитиною соціально значущих цінностей. Перспективність цієї роботи полягає у розширенні засад дитячої психології щодо розвитку психічних новоутворень старшого дошкільника та умов збереження простору дитячої субкультури, гармонізації системи «людинасвіт».

Психолого-педагогічні дослідження проблеми ціннісних орієнтирів людини розглянуто у багатьох аспектах. У вітчизняних і зарубіжних працях 3 гуманістичної психології ціннісно-смислова сфера особистості була предметом дослідження таких науковців, як А. Маслоу, К. Роджерс, Г. Олпорт, В. Франкл, Е. Фромм, Л. Виготський, О. Леонтьев, С. Рубінштейн, Г. Костюк, Л. Божович, Г. Балл, М. Боришевський, Н. Чепелєва, С. Максименко. Підтверджено, що формуючись, як і потреби, в індивідуальному досвіді суб'єкта, особистісні цінності відбивають не так динамічні аспекти індивідуального досвіду, як інваріантні аспекти соціального і загальнолюдського досвіду, що привласнюється індивідом.

3 психологічної точку зору категорія «цінність» $\epsilon$ особливим видом реальності. Сама по собі вона не існує. Цінність завжди пов'язана з конкретною людиною, точніше з їі ставленням до предмета зі світу суб'єктивної реальності. Відповідно ми маємо цінності матеріальні (речі, гроші, матеріальні блага), цінності художні (твори мистецтва та літератури), цінності природні (краса природи, схід сонця, морський бриз, гірське повітря), цінності людські (любов, радість, мужність, вчинок). Цінність чогось може бути цінністю, лише коли це щось $€$ значущим для когось, для конкретної людини. Якщо число людей, які визнають певну цінність, $\epsilon$ великим, ми говоримо про існування загальнолюдських чи так званих «вічних» цінностей (добро, краса, справедливість та ін.).

Створення передумов до збереження цілісності особистості дитини дошкільного віку, становлення соціально значущих якостей особистості у період вікової кризи регуляції поведінки в
6(7) років в умовах зміни соціальної ситуації розвитку (дошкільна - початкова освіта), формування суб'єктної позиції дитини старшого дошкільного віку в ситуації вибору значущих цінностей характеризують соціальний ефект від упровадження освітньої системи «Радість розвитку». Система спрямована на гармонізацію потенціалу і ресурсу природних сил дитини, включаючи ї̈ фізичний, соціальний, інтелектуальний, духовний розвиток.

Можна стверджувати, що головним висновком усіх порівнянь, спостережень, аналітичних коментарів науковців і педагогів, учасників експериментальної роботи у проєкті «Психологопедагогічні умови становлення ціннісних орієнтацій дітей в ігровій та навчальній діяльності освітньої системи «Радість розвитку» $€$ те, що психологічна ознака розвивального середовища, в якому актуалізується творчість дитини - це високий ступінь невизначеності та варіативності. Невизначеність стимулює пошук власних орієнтирів, а не прийняття готових; варіативність забезпечує можливість їх знаходження. Розвивальними слід вважати умови, які підживлюють природні сили дитини, сприяють реалізації потенційних можливостей, збагачують знаннями основ філософії життя і практичними навичками, вдосконалюють їх, забезпечують усвідомленість, культурність, міцність; позитивно впливають на становлення особистісного досвіду, формують реалістичні образи світу та власного «Я». Тобто формат/ спосіб організації життєдіяльності дорослого 3 дітьми - головний зовнішній соціальнопедагогічний чинник розвитку дитини.

Тому не випадково визначення балансу методичних прийомів, методів і форм роботи дорослих для провідної у дошкільників ігрової діяльності та поступового становлення навчальної, що дає змогу засвоїти нову соціальну роль і статус школяра, $\epsilon$ теоретично значущим і практично необхідним предметом наукового аналізу експериментальної роботи, де відбувається психологопедагогічне проєктування взаємодії дорослого й дитини.

Проблема посилюється в реальних умовах переходу дитини до школи. Понад 30 \% дітей по досягненню 6 років щороку залишаються в умовах дитячого садочку з різних причин (стан здоров'я, соціальна дезадаптації сім'ї та ін.). Тому в один клас початкової школи приходять діти вже 8 року життя i ті, кому щойно виповнилось 6 років. I така вікова диференціація ніяк не 
враховується в організації освітнього процесу початкових класів школи.

Центральною і головною ідеюю на шляху впровадження освітньої системи «Радість розвитку» $\epsilon$ твердження, що спосіб організації життя дитини в умовах різних освітніх установ потребує врахування провідних для неї видів ігрової та навчальної діяльності через об'єднання змісту навчання у межах тематичного циклу. Такий спосіб дає змогу реалізувати психологопедагогічні умови свободи й прийняття дитиною цінностей, які $\in$ механізмом активності, творчої діяльнісної самореалізації та самопрезентації особистості в оточенні ровесників та дорослих. Тематичні цикли як послідовність етапів проєктованої взаємодії дорослого з дітьми містять ціннісно-смислові акценти і виступають інструментом інтеграції змісту та завдань державних освітніх програм діяльності навчальних закладів. Необхідність доповнення та переосмислення чинників і рушійних сил індивідуалізації психічного, соціального, духовного розвитку дитини старшого дошкільного віку на етапі переходу від дошкільної до початкової освіти підкреслюється тим, що в сучасному суспільстві ціннісно-смислова сфера особистості формується не лише під впливом традиційних чинників (сім'я, оточення однолітків), а й під впливом нових факторів (3МІ, інтернет, комп'ютерні ігри). Це потребує поглибленого їх вивчення як факторів впливу.

Цільовою групою користувачів результатів експериментального дослідження $€$ : науковціпсихологи, вихователі дошкільних навчальних закладів, батьки вихованців, практичні психологи, які працюють у галузі освіти, викладачі, які здійснюють професійну підготовку фахівців.

Відповідно до технічного завдання науководослідну роботу «Психолого-педагогічні умови становлення ціннісних орієнтацій дітей в ігровій та навчальній діяльності освітньої системи «Радість розвитку» розпочато в таких освітніх закладах: СЗШ №№ 9, 231, 233, ЗДО №№ 523, 573, 580 «Ольвія» Оболонського району м. Києва; ЗДО № 31 «Мир» м. Костянтинівка Донецької обл.; СЗШ № 8 м. Житомир; Макарівський навчально-виховний комплекс «Загальноосвітня школа I-ІІІ ступенів - природничо-математичний ліцей» с. Макарів Київської обл., НВК «Кіровоградський колегіум». Усього цю технологію у контексті аналізу ігрової та навчальної діяльності здійснено на базі дванадцяти закладів освіти (п'яти початкових шкіл, двох навчально- виховних комплексів та п'яти закладів дошкільної освіти) з 2015 p.

Реалізація експериментального проєкту передбачає системне об'єднання інституцій різного типу: Інституту психології імені Г.С. Костюка НАПН України, закладів дошкільної, загальної середньої та вищої освіти, що дає змогу швидко реагувати на соціальні та освітні ініціативи. Виходячи з концептуальних положень експериментальної роботи $з$ упровадження освітньої системи «Радість розвитку» на етапі збору даних, зареєстровано інформацію про: загальний емоційний

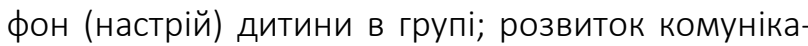
тивних навичок (взаємодія та спілкування); вмотивованість до діяльності; готовність до спільної діяльності; самооцінку; рівень очікувань; впевненість у собі під час ігрової та навальної діяльності; критерії та показники системи ціннісних орієнтацій дітей. Серед методів діагностичної роботи використано: спостереження; анкетування; аналіз продуктів творчої діяльності; метод експертних оцінок. Діагностичний комплекс становлять методики: «Профіль класу» (Т.О. Піроженко, О.С. Рогозянський, О.Ю. Хартман), «Експресдіагностика сфери ціннісних орієнтацій дитини» (Т.О. Піроженко, К.В. Карасьова, С.О. Ладивір, Л.І. Соловйова). Алгоритм діагностичного етапу у формувальних і контрольних групах респондентів відображає специфіку організації освітньої роботи з дітьми в дошкільних закладах і початкових класах школи: 1 серія обстеження - вересень 2016 р.; 2 серія - травень 2017 р.; 3 серія - вересень 2017 р.; 4 серія - травень 2018 р.

Аналіз процесу становлення ціннісних орієнтацій дітей в ігровій і навчальній діяльності дав змогу виокремити не тільки зовнішні (соціальнопедагогічні), а й внутрішні (психологічні) фактори впливу на процес прийняття дитиною соціально значущих цінностей.

Проілюструємо ці здобутки досягненнями дітей і педагогів експериментальних закладів дошкільної освіти. Зведені у таблиці та діаграми результати моніторингу експериментальних контрольних груп відображають динаміку змін за весь період експериментального педагогічного дослідження (див. презентацію).

Статистичний аналіз отриманих даних підтвердив динамічний і якісний стрибок у ціннісних орієнтаціях дитини старшого дошкільного віку як регуляторах взаємовідносин між ровесниками та членами своєї родини, а також продемонстрував ціннісне відношення до різних видів діяльності. 


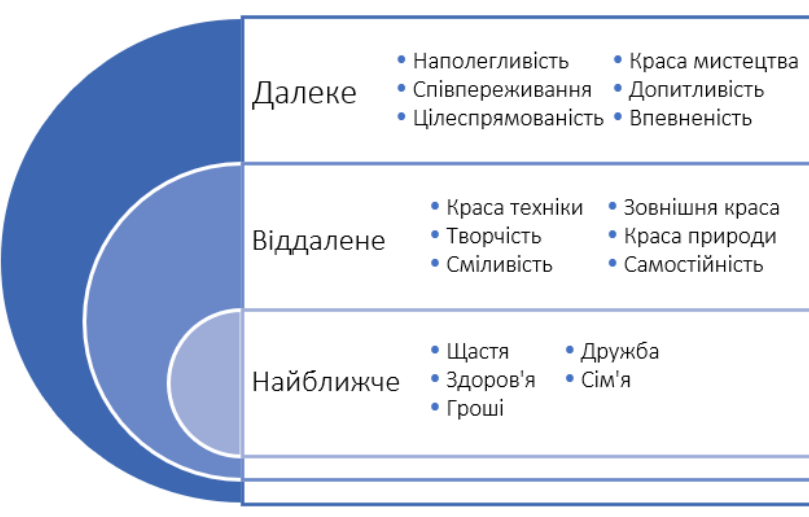

Рис. 1. Модель ієрархічної будови

поля цінностей старших дошкільників

Спільним для розгортання цінностей є активізація їх прояву у самодіяльній, творчій, тобто емоційно значущій діяльності. Експериментальні дані дають змогу зазначити, що попри усі індивідуально-варіативні особливості процесу становлення ціннісних орієнтацій, вони змістовно збагачуються сенсом, здатністю дитини їх мовно та мотивовано виражати. Цінності дитини змінюються у бік більшої диференційованості (емоційних, когнітивних, діяльнісних компонентів стає більше), повноти (перехід від зовнішніх характеристик до поведінкових проявів, відповідність особистісним особливостям і смисловим категоріям), усвідомленості (зростає вагомість та значущість усвідомлюваних компонентів) і стійкості (зростає кількість постійних ознак та якостей, за допомогою яких описуються ціннісні орієнтації дошкільників). Тобто внутрішній (психологічний) чинник стає основним у процесі присвоєння цінностей, які $€$ регулятором соціальних відносин та особистісної самопрезентації.

Визначено, що серед усіх критеріїв оцінки особистісних якостей респондентів найвагоміший внесок до здатності дитини приймати та вибирати соціально значущі цінності роблять фактори «світоглядні уявлення та мовлення», «етичні інстанції» та поведінкові ознаки. Це підтверджує позицію дослідників, що категорія «ціннісна орієнтація» дошкільника може бути представлена якісними характеристиками з погляду структурної цілісності психіки дитини в єдності емоційних, когнітивних і регулятивних ознак.

Представимо характеристику системи цінностей старших дошкільників, які виховуються у дошкільних закладах освіти та перших класах початкової школи, в двох напрямах: широта та змістовна наповненість системи цінностей 3 дитячої субкультури життя («Поле цінностей дитини», рис. 1) та психологічні особливості

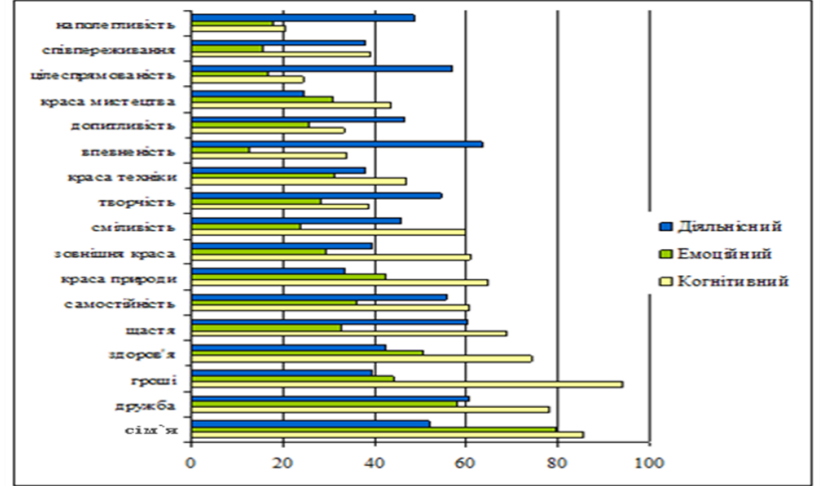

Рис. 2. Рівні актуалізації ціннісних орієнтацій старших дошкільників за їх структурними компонентами

процесу становлення цінностей у дитини дошкільного віку («Структурно-динамічні характеристики ціннісних орієнтацій», рис. 2).

Характеристика цінностей дитини старшого дошкільного віку з погляду змістового наповнення та структурних особливостей дає уявлення про унікальну структуру глибинного змісту індивідуальних переваг конкретної особистості. Виявлення емоційних переваг, когнітивного наповнення та фактичного існування (прояву) ціннісних орієнтацій дає змогу розрізнити емоційні, когнітивні та регулятивні якісні характеристики в структурі ціннісних орієнтацій дитини старшого дошкільного віку та відокремити «значущі», «знані» та «дієві» цінності. Привласнюючи різні цінності, дитина починає самостійно, свідомо керуватися ними в різних видах діяльності у грі, у навчанні, в праці, поступово набуваючи досвіду їх ефективної реалізації. За допомогою уявлень про норми, цінності, ідеали людина регулює не тільки свою поведінку, а й, даючи їм оцінку, виявляє своє ставлення до вчинків інших, чим реально творить суспільні взаємозв'язки у найближчому оточенні. Можна стверджувати, що атмосфера підтримки в групі однолітків, взаєморозуміння, соціальне та психічне благополуччя - це реальний внесок, який робить кожна дитина завдяки дієвості особистих ціннісних орієнтацій.

За результатами проведеного обстеження ми можемо констатувати наступне (табл. 1). У дітей старшого дошкільного віку і молодшого шкільного віку термінальні та інструментальні цінності розподілились однаково пропорційно: 6 з 9 термінальні, 3 з 9 - інструментальні. Поле значущих цінностей у старших дошкільників і першокласників на $50 \%$ (5 з 9) збігається. При цьому пари цінностей, що відрізняються, збігаються за типами. 
Відмінності поля цінностей дітей старшого дошкільного та молодшого шкільного віку

\begin{tabular}{|l|l|l|}
\hline \multicolumn{2}{|c|}{ Вік дітей } & \multirow{2}{*}{ Групка цінностей } \\
\cline { 1 - 2 } щастя & $\begin{array}{c}\text { Молодші } \\
\text { школярі }\end{array}$ & \multicolumn{1}{|c|}{$\begin{array}{l}\text { термінальна } \\
\text { (цінності-блага) }\end{array}$} \\
\hline краса мистецтва & творчість & $\begin{array}{l}\text { термінальні } \\
\text { (цінності-блага) }\end{array}$ \\
\hline співпереживання & сміливість & $\begin{array}{l}\text { інструментальні } \\
\text { (цінності-регламенти) }\end{array}$ \\
\hline цілеспрямованість & наполегливість & $\begin{array}{l}\text { інструментальні } \\
\text { (цінності-регламенти) }\end{array}$ \\
\hline
\end{tabular}

Це дає нам підстави стверджувати, що змістовна (якісна) сторона поля соціально значущих цінностей залишається незмінною на перехідному етапі від дошкільної та початкової освіти. Статистично доведена відсутність істотних відмінностей між даними дітей - вихованців дитячого садка та першого класу школи викликає занепокоєння, оскільки вказує на те, що ціннісні орієнтації у ситуації вікової кризи регуляції поведінки не виконують своєї стабілізуючої ролі у самостійному керуванні поведінкою на подальших латентних періодах розвитку.

Аналіз експериментальних даних також дав змогу скласти рейтинг соціально значущих цінностей дітей старшого дошкільного віку. Дані представлено відповідно до рейтингових місць (частоти виборів) цінностей у кожній вибірці респондентів (табл. 2).

Рангове представлення цінностей становить три групи найважливіших, віддалених і далеких цінностей. Перша група: сім'я, здоров'я, сміливість, краса природи, дружба, гроші, творчість, самостійність. Друга група: щастя, наполегливість, співпереживання, зовнішня краса людини. Третя група: краса техніки, впевненість, краса мистецтва, допитливість, цілеспрямованість.

Визначення рейтингу цінностей у житті дитини спрямувало аналіз внутрішніх чинників, якими $\epsilon$ вікові психічні новоутворення, що пояснюють існування діючих у реальному житті дитини цінностей. Тому окремим завданням стало визначення рівня особистісного розвитку кожного респондента та ваги кожного з психологічних новоутворень особистості в характеристиці існуючих ціннісних орієнтацій дитини.

Згідно з набором емпіричних даних рівень особистісного розвитку це - оцінка характеристик за рівнями сформованості внутрішніх психічних новоутворень дитини. У нашому дослідженні це світоглядні уявлення, етичні інстанції у взаємодії з однолітками та дорослими, мислення, мовленнєвий розвиток, довільна поведінка, мотиваційна складова.

Відповідно до алгоритму обробки результатів діагностичної бесіди «Чинники вибору дитиною соціально значущих цінностей» ми мали можливість визначити такі рівні сформованості світоглядних уявлень: високий - сформована картина світу; рівень вище середнього - виражені світоглядні уявлення; середній - є світоглядні уявлення; рівень нижче середнього - обмежені світоглядні уявлення; низький рівень - фрагментарні світоглядні уявлення.

У вибірці респондентів віком 5-6 років зафіксовано такі результати (табл. 3, рис. 3). Високий рівень світоглядних уявлень мають 57,89\% (55 осіб); рівень вище середнього - 13,68\% (13 осіб); середній рівень $20 \%$ (19 осіб); рівень

Табличя 2

Рейтинг соціально значущих цінностей дітей 6(7) років життя

\begin{tabular}{|c|c|c|c|c|}
\hline \multirow{2}{*}{$\begin{array}{c}\text { Група рейтингу } \\
\text { цінностей (місце) }\end{array}$} & \multicolumn{4}{|c|}{ Цінності } \\
\hline & Загальна вибірка & Схід України & Центр України & Захід України \\
\hline I & $\begin{array}{l}\text { Краса природи } \\
\text { Творчість } \\
\text { Здоров'я } \\
\text { Сім'я }\end{array}$ & $\begin{array}{l}\text { Сім'я } \\
\text { Творчість } \\
\text { Здоров'я } \\
\text { Краса природи }\end{array}$ & $\begin{array}{l}\text { Творчість } \\
\text { Сім'я } \\
\text { Краса природи } \\
\text { Здоров'я }\end{array}$ & $\begin{array}{l}\text { Краса природи } \\
\text { Творчість } \\
\text { Здоров'я } \\
\text { Сім'я }\end{array}$ \\
\hline II & $\begin{array}{l}\text { Самостійність } \\
\text { Гроші } \\
\text { Дружба } \\
\text { Сміливість }\end{array}$ & $\begin{array}{l}\text { Дружба } \\
\text { Гроші } \\
\text { Самостійність } \\
\text { Сміливість }\end{array}$ & $\begin{array}{l}\text { Дружба } \\
\text { Самостійність } \\
\text { Гроші } \\
\text { Сміливість }\end{array}$ & $\begin{array}{l}\text { Гроші } \\
\text { Самостійність } \\
\text { Сміливість } \\
\text { Дружба }\end{array}$ \\
\hline III & $\begin{array}{l}\text { Співпереживання } \\
\text { Наполегливість } \\
\text { Зовнішні краса людини } \\
\text { Щастя }\end{array}$ & $\begin{array}{l}\text { Зовнішня краса людини } \\
\text { Наполегливість } \\
\text { Щастя } \\
\text { Співпереживання }\end{array}$ & $\begin{array}{l}\text { Щастя } \\
\text { Зовнішня краса людини } \\
\text { Співпереживання } \\
\text { Наполегливість }\end{array}$ & $\begin{array}{l}\text { Наполегливість } \\
\text { Зовнішня краса людини } \\
\text { Співпереживання } \\
\text { Щастя }\end{array}$ \\
\hline
\end{tabular}


Табличя 3

Взаємозв'язок рівнів сформованості світоглядних уявлень із рівнем особистісного розвитку (параметр аналізу: загальна вибірка респондентів, відносний показник)

\begin{tabular}{|l|c|c|c|c|c|c|}
\hline \multirow{2}{*}{$\begin{array}{c}\text { Рівні } \\
\text { сормо- } \\
\text { ваності } \\
\text { світог- } \\
\text { лядних } \\
\text { уявлень }\end{array}$} & $\begin{array}{c}\text { низь- } \\
\text { кий } \\
\text { рівень } \\
\text { ОР }\end{array}$ & $\begin{array}{c}\text { рівень } \\
\text { нижче } \\
\text { серед- } \\
\text { нього } \\
\text { ОР }\end{array}$ & $\begin{array}{c}\text { серед- } \\
\text { ній } \\
\text { рівень } \\
\text { ОР }\end{array}$ & $\begin{array}{c}\text { рівень } \\
\text { вище } \\
\text { серед- } \\
\text { нього } \\
\text { ОР }\end{array}$ & $\begin{array}{c}\text { висо- } \\
\text { кий } \\
\text { рівень } \\
\text { ОР }\end{array}$ & $\begin{array}{c}\text { кіль- } \\
\text { кість }\end{array}$ \\
\hline $\begin{array}{l}\text { високий } \\
\text { рівень СУ }\end{array}$ & 0,00 & 1,23 & 54,32 & 30,86 & 12,35 & 81 \\
\hline $\begin{array}{l}\text { рівень } \\
\text { вище сере- } \\
\text { днього СУ }\end{array}$ & 0,00 & 9,38 & 90,63 & 0,00 & 0,00 & 32 \\
\hline $\begin{array}{l}\text { середній } \\
\text { рівень СУ }\end{array}$ & 10,71 & 57,14 & 32,14 & 0,00 & 0,00 & 28 \\
\hline $\begin{array}{l}\text { рівень } \\
\text { нижче } \\
\text { середнього } \\
\text { су }\end{array}$ & 23,08 & 69,23 & 7,69 & 0,00 & 0,00 & 13 \\
\hline
\end{tabular}

нижче середнього - 8,42\% (8 осіб). У вибірці респондентів віком 6-7 років зафіксовано такі результати: високий рівень світоглядних уявлень мають 43,10\% (25 осіб); рівень вище середнього - 32,76\% (19 осіб); середній рівень 15,52\% (9 осіб); рівень нижче середнього - 8,62\% (5 осіб). 3 низьким рівнем сформованості світоглядних уявлень не виявлено жодного респондента з усієї вибірки.

Як видно з представлених даних, сформована картина світу (високий рівень сформованості світоглядних уявлень) та виражені світоглядні уявлення (рівень сформованості світоглядних уявлень вище середнього) були лише у дітей, які мають високий рівень особистісного розвитку 12,35\% та 30,86 \% відповідно. У підгрупі респондентів із середнім рівнем особистісного розвитку зафіксовано частки всіх рівнів сформованості світоглядних уявлень. У поле цінностей дітей

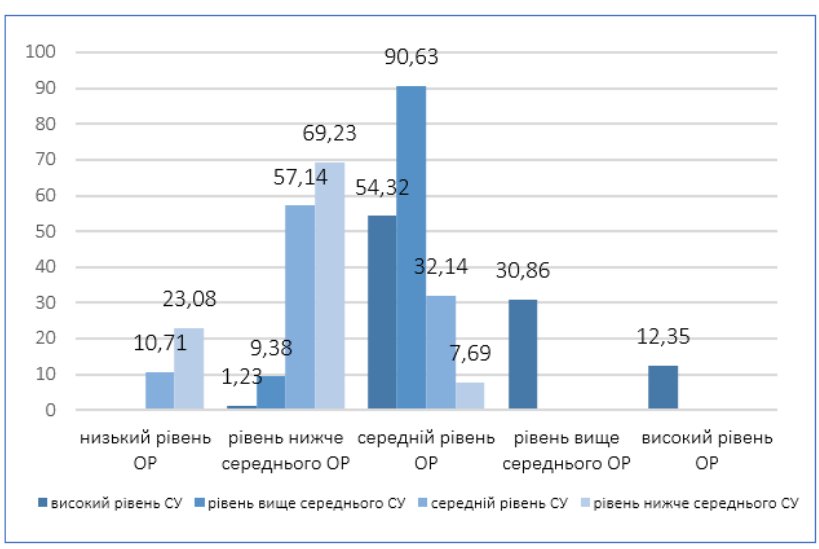

Рис. 3. Взаємозв'язок рівнів сформованості світоглядних уявлень із рівнем особистісного розвитку (параметр аналізу: загальна вибірка респондентів) входять соціально значущі цінності, серед яких знайшлось місце для вічних цінностей - щастя, родина, дружба, зміст та логічне обґрунтування яких відображено у відповідях дітей. Дитина старшого дошкільного віку здатна до узагальнення, свідомого вибору та диференціації соціально значущих цінностей. Приклади відповідей «Без сім'ї не можливо бути щасливим» або «Щастя це коли в тебе $є$ і мама, і тато, і брат, і сестра...» підтверджують це.

Співвідношення вибору соціально значущих цінностей, рівня особистісного розвитку із рівнем сформованості світоглядних уявлень має споріднену тенденцію. Тобто загальна тенденція розподілу часток у групах респондентів «старші дошкільники» та «молодші школярі (учні 1-х класів)» за всіма параметрами аналізу зберігається.

Кількісний і якісний аналіз емпіричних даних дає нам можливість стверджувати, що за суттю розгортання психічного розвитку дитина 6(7)річного віку залишається дошкільником. Отже, в практиці виховання та навчання дітей необхідно враховувати параметр психологічної зрілості дошкільника.

Можемо говорити про перші ознаки спрямованості свідомості дитини. Вибір як акт активності дитини в її життєдіяльності набуває нового сенсу - виконує роль чинника мотивації та вольової регуляції. Предмет вибору залежить від прийнятих дитиною, тобто соціально значущих для неї цінностей.

Пошук взаємозв'язків між вибором дитиною ціннісних орієнтацій та сформованістю загальнопсихічних якостей розвитку старшого дошкільника, що розглядаються у нашому дослідженні як внутрішні чинники прийняття соціально значущих цінностей, спрямував подальший аналіз бази даних, у якому знайдено фактор другого порядку. Він з'єднує три фактори з характеристиками, що не належать до ціннісних орієнтацій, проте характеризують рівень психологічної зрілості дитини старшого дошкільного віку через сформованість їі психологічних досягнень (емоційний, пізнавальний розвиток, довільна регуляція поведінки). Соціально значущі цінності засвоюються дітьми на когнітивному (може пояснити, що це таке; має уявлення), на емоційному (знаю, що так правильно, але не завжди так роблю), на діяльнісному (керується у повсякденному житті) рівнях.

Статистичне (Т.О. Піроженко, О.С. Рогозянський) підтвердження рангових виборів соціально значущих цінностей і сформованість 
емоційного компонента характеризує суб'єктивне, особистісне відношення до предмета оцінювання в оточуючій природній і соціальній дійсності та проявляється через ступінь емоційної насиченості в оцінних судженнях і знаннях (I.І. Карабаєва, Л.Д. Токарєва, О.І. Федорчук). Можливість вибору та прийняття дитиною соціально значущих цінностей залежить від їі когнітивного (пізнавального) розвитку та виявляється через змістову наповненість, насиченість оцінних суджень, знань про оточуючу дійсність та саму себе, тобто понять, які означають систему ціннісних орієнтирів дитини (С.О. Ладивір, О.Ю. Хартман). Факт прийняття дитиною соціально значущих цінностей характеризує ступінь включення оцінних суджень у реальну життєдіяльність дитини та аналізується за ступенем сформованості регулятивних механізмів поведінки в різних специфічно дитячих видах діяльності (Л.І. Соловйова).

Співвідношення та узгодженість вибору соціально значущих цінностей з рівнем сформованості структурно-динамічних характеристик ціннісної орієнтації, яка представлена єдністю її компонентів, вказує на здатність до прийняття та вибору дитиною старшого дошкільного віку цінностей як пріоритетних індикаторів особистісного зростання. Ціннісні орієнтації $є$ характеристикою зростаючих можливостей дитини дошкільного віку у свідомому виявленні психологічного простору «Я». У ціннісних орієнтаціях відбивається рівень суб'єктної активності дитини, ступінь дорослішання і гармонізації усіх психологічних надбань, що проявляється у поведінці, відносинах з іншими людьми, в пізнавальній і предметно-практичних видах діяльності (Піроженко, Хартман, 2014; Піроженко та ін., 2014a; Піроженко та ін., 2014b; Піроженко та ін., 2016; Піроженко та ін., 2016; Піроженко, Соловйова, Хартман, 2017; Піроженко та ін., 2017).

Отже, аналіз результатів цього етапу дослідноекспериментальної роботи дає змогу стверджувати: вибір соціально значущих цінностей напряму взаємопов'язаний із рівнем психологічної зрілості дитини. Найвагоміший внесок до процесу вибору та прийняття дитиною цінності здійснює внутрішній фактор, тобто загальний рівень психічного розвитку дитини дошкільного віку, ступінь дошкільної зрілості. Так, дитина вправляється, за словами Л.С. Виготського, у вільному виборі між двома можливостями, який визначається не ззовні, а зсередини самою дитиною.
Статистичне підтвердження гіпотези наукового дослідження щодо вибору соціально значущих цінностей, які взаємопов'язані з рівнем психологічної зрілості дитини, спрямовує головний орієнтир зовнішніх психолого-педагогічних впливів дорослих. Усі дорослі, які опікуються дитинством, мають об'єднати зусилля для розкриття внутрішнього потенціалу дитини - сформованості емоційної зрілості, здібностей до пізнання оточуючого світу, до регуляції поведінки та діяльності. Дошкільна зрілість, що характеризується через розвиненість психологічних якостей, взаємопов'язана із найскладнішим феноменом психіки ціннісними орієнтаціями, які так само виконують функцію орієнтації у соціальному, природному, технічному середовищі, та функцію регуляції особистісної активності у всіх сферах існування «людина-людина», «людина-природа», «людина -мистецтво», «людина-техніка». Освітня система, в якій приділяється підвищена увага до творчого рівня усіх специфічно дитячих видів діяльності (пізнавальної, образотворчої, ігрової), постійно вправляє дитину у прояві саме суб'єктних, особистісних регуляторів активності.

Узгоджені напрями взаємодії дорослих (педагогічної команди) 3 дитиною в ігровій i навчальній діяльності за програмою комплексного розвитку особистості дитини «Радість розвитку» в умовах навчальної діяльності дітей перших класів підтверджує тенденції ефективного впливу збалансованого психолого-педагогічного розподілу репродуктивних і творчих видів діяльності, важливості збереження ігрових і навчальних методів в організації життєдіяльності дітей. Зокрема, досвід взаємодії дорослих (педагогічної команди) з дітьми в початкових класах школи в ігровій та навчальній діяльності вказує на позитивну динаміку особистісних змін розвитку дітей. У період з жовтня 2016 р. по травень 2018 р. характеристики комунікації (мовлення) покращились на $17 \%$, мотивація навчальної діяльності - на $16 \%$, організаційні навички взаємодії - на $9 \%$, самооцінка та рівень очікувань - на $5 \%$, загальний емоційний фон/настрій у групі змінився на $6 \%$. Загалом за перший рік навчання дітей у школі, де впроваджується освітня технологія «Радість розвитку», всі показники мають позитивну динаміку $5 \%$, на кінець другого року навчання позитивна динаміка становить $12 \%$, що вказує на стабільну загальну динаміку в розвитку пізнавальних інтересів, упевненість у власних силах, товариський характер стосунків між дітьми, 
здатність до регуляції своєї поведінки і діяльності. Експериментальні дані засвідчують, що дієвість ціннісних орієнтацій дітей збільшується в умовах їх прояву у самодіяльній, емоційно значущій для дитини діяльності. Використання освітньої системи «Радість розвитку» надає змогу організації навчання і виховання дітей за тематичними циклами з урахуванням вікових особливостей, темпу індивідуального розвитку, психологічних новоутворень зростаючої особистості, а також створює умови становлення ціннісних орієнтацій як внутрішньої системи координат активності дітей і молоді. Тематичні цикли дають можливості привласнення кожною дитиною особистісних досягнень: від створення спільного творчого задуму до реалізації образу результату і рефлексії особистого досвіду. Організація життя дитини у збалансованому співвідношенні ігрової та навчальної діяльності в межах тематичного циклу дозволяє реалізувати психолого-педагогічні умови свободи й прийняття цінностей і забезпечити творчу самопрезентацію особистості.

Специфіка самоорганізації взаємодії дорослих 3 дітьми та молоддю забезпечує збереження субкультури дитинства: орієнтацію виховних впливів на мету кожного вікового періоду, врахування психічних новоутворень кожної дитини, вибір форм і методів взаємодії дорослого з дитиною відповідно до провідного виду діяльності. Організація освітнього процесу (ігрової та навчальної діяльності) за освітньою системою «Радість розвитку» дає змогу для наступності особистісного розвитку на всіх ланках освіти (дошкільна, початкова, середня).

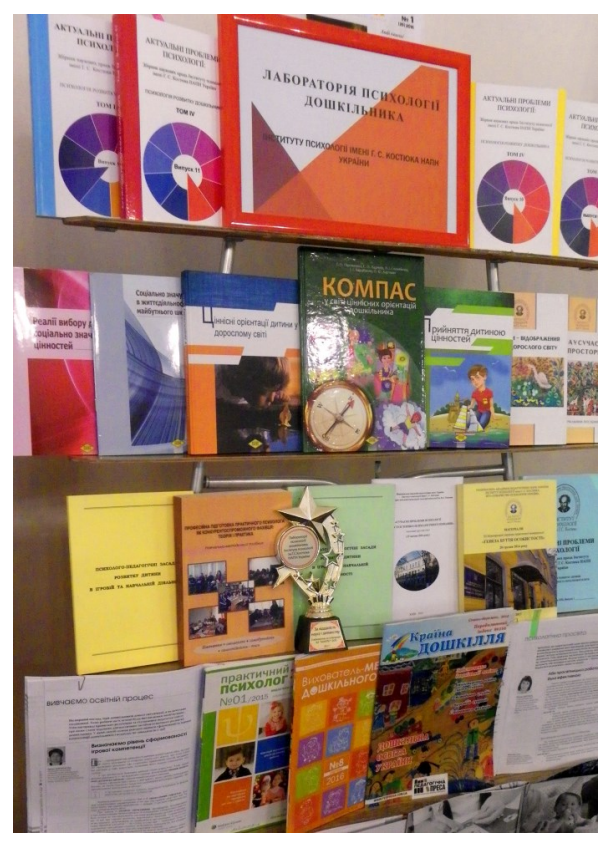

Досвід теоретичного та експериментального аналізу проблеми ціннісних орієнтацій дітей як духовного виміру зростаючої особистості широко представлений для фахівців і батьків вихованців дошкільних закладів освіти через програмнометодичні матеріали, що відображають змістовне спрямовання спільних дій дорослих, які опікуються дитинством. Для цього було здійснено реалізацію проєктів: «Вчимося жити разом» для дітей регіонів, що опинилися у конфліктній соціальній ситуації розвитку. Комплект «Вчимося жити разом» (гриф МОН, 2016) з розвитку соціальних навичок ефективної взаємодії дітей від 4 до 67 років був ініційований Представництвом Дитячого фонду ООН (ЮНІСЕФ) в Україні для дітей, які проживають або опинились в зоні конфлікту. Автори (Т.О. Піроженко, О.Ю. Хартман) активно втілюють пропозиції та досвід навчання тренерів для вихователів, психологів, управлінців дошкільної освіти в Запорізькій, Донецькій, Дніпропетровській, Луганській, Харківській областях України (Піроженко, Хартман, Палієнко, Павленко, 2016; Парціальна програма з розвитку соціальних навичок ефективної взаємодії дітей від 4 до 67 років «Вчимося жити разом», 2016) .

Навчально-методичний комплект «Впевнений Старт» (Піроженко, Хартман, 2014; Гавриш та ін., 2017a; Гавриш та ін., 2017b; Климець, Піроженко, 2016) складається з освітньої програми для дітей старшого дошкільного віку та 12 посібників для всіх учасників освітнього процесу, а саме: для дітей - «Впевнений старт: книга дошкільника» (в 3 частинах), «Впевнений старт: альбом з художньо-творчої діяльності» (в 3 частинах); для

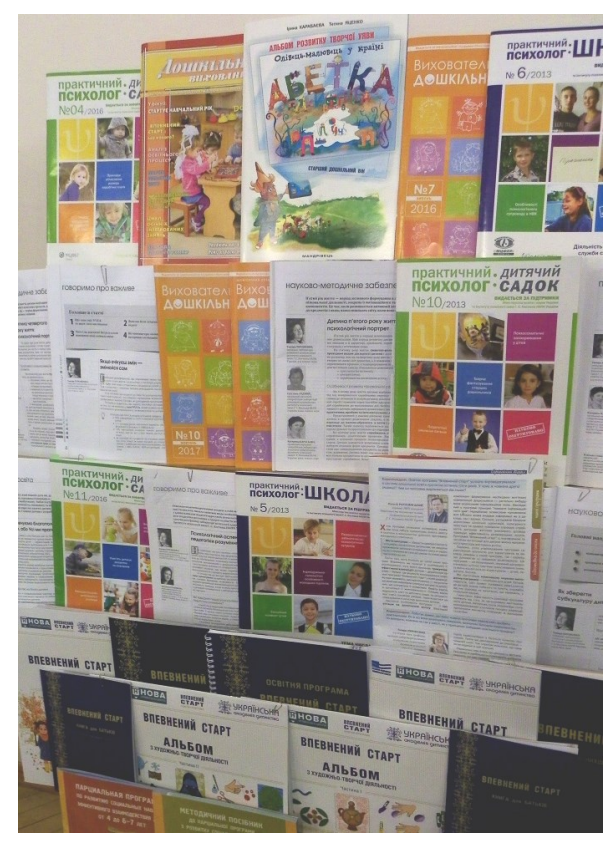
педагогів - «Впевнений старт: книга вихователя» (в 3 частинах); для батьків - «Впевнений старт: книга для батьків» (в 3 частинах). Доповненням до комплекту $\epsilon$ сучасний Інтернет-портал https://vstart.com.ua, на якому зібрано додатковий контент для роботи вихователів.

Інститут психології імені Г.С. Костюка НАПН України на $X$ Міжнародній виставці «Інноватика в сучасній освіті - 2018» здобув золоту медаль в 
номінації «Інноваційне освітнє середовище: нові виклики та сучасні рішення») за Комплект навчально-методичних матеріалів «Впевнений старт» (науковий керівник проєкту - Т.О. Піроженко). 32 січня 2018 р. по 20 травня 2018 р. проведено 16 семінарів-тренінгів у 12 областях України (Чернівецька, Донецька (3), Житомирська, Сумська, Хмельницька, Харківська (2), ІваноФранківська, Чернігівська, Полтавська, Запорізька, Тернопільська, Київська). Підготовлено 515 тренерів, які провели семінари районного рівня (390). Проведено Всеукраїнський вебінар «Забезпечення наступності змісту дошкільної і початкової освіти: впровадження освітньої програми «Впевнений старт» у практику роботи 3 дітьми старшого дошкільного віку» (режим онлайн, 18 квітня 2018 р., МОН України, м. Київ). Обраний формат проведення семінару дав змогу об'єднати багатьох учасників (понад 20 тисяч переглядів). Пряму трансляцію переглянули близько 500 осіб.

Навчально-методичний комплект «Впевнений старт: середня група» має гриф МОН України (2019 р.). Комплект матеріалів для груп середнього дошкільного віку складається 3: «Впевнений старт: книга вихователя» (методичний посібник у 3 частинах) із додатком «Набір плакатів для групової роботи»; «Впевнений старт: набір розвивальних завдань для дітей середнього дошкільного віку» (навчальне видання); «Впевнений старт: альбом із художньо-творчої діяльності» (навчальне видання у 2 частинах).

Інноваційний проєкт «Впевнений старт» для дітей середнього дошкільного віку (освітня програма і 8 посібників) авторського колективу під керівництвом Т.О.Піроженко став лауреатом конкурсу «Національне визнання наукових досягнень» XI Міжнародної виставки «ннноватика в сучасній освіті - 2019» у номінації «ннноваційний проєкт, педагогічна технологія».

Підтримка педагогів-практиків системно продовжується у форматі підготовки «тренінг тренерів» в 12 областях України.

Ці розробки є прикладом сучасного рішення навчально-методичного забезпечення інноваційного освітнього процесу в закладах дошкільної освіти України та можуть слугувати варіантом українського продукту для цілей міжнародного співробітництва з партнерами у галузі освіти дітей. Обговорення таких питань зорієнтовано на узгодження спільних дій дорослих, які опікуються розвитком дітей. Це робить освітню діяльність дорослих більш професійно-компетентною, свідомою, якісною, спрямованою на отримання суспільно значущого результату - збереження людського ресурсу, дитячої субкультури та творчого потенціалу дитинства.

Реалізація експериментальної роботи, що спирається на сучасні теоретичні дослідження, вносить в освітній простір нову якість:

- взаємозв'язок науки та практики;

- координованість і співпраця з усіма партнерами (діти, батьки вихованців, педагоги);

- гнучкість, стійкість та адаптивність вибору форм і методів навчально-виховної роботи педагогів, який спирається на індивідуальний потенціал дитини та дитячої групи;

- виступає психологічно обґрунтованим педагогічним інструментарієм реалізації особистісно орієнтованої освітньої практики дітей дошкільного та молодшого шкільного віку.

Отже, вважаємо за необхідне підкреслити питання: збалансованого підходу щодо змісту та форм організації взаємодії дорослого з дитиною, який забезпечує збереження та своєчасну підтри мку базисних вікових характеристик особистості дошкільника; реалізації завдань наступності між дошкільною та шкільною ланками освіти, що в умовах безпрецедентної динаміки змін, трансформацій та протиріччя між розвивальними, виховними, навчальними цілями освіти запобігає деформації педагогічного процесу в бік одностороннього домінування навчальних цінностей.

Виходячи із наведеної інформації, вважаємо, що творчий колектив науковців лабораторії психології дошкільника Інституту психології імені Г.С. Костюка НАПН України та педагогів експери ментальних майданчиків закладів дошкільної та початкової освіти успішно впроваджує експери ментальне дослідження «Психолого-педагогічні умови становлення ціннісних орієнтацій дітей в ігровій та навчальній діяльності освітньої системи «Радість розвитку».

\section{СПИСОК ВИКОРИСТАНИХ ДЖЕРЕЛ}

Гавриш, Н.В., Брежнєва, О.Г., Кіндрат, І.Р., Корнеєва, О.Л., Рагозина, В.В., Рогозянський, О.С., \& Хартман, О.Ю. (2017а). Впевнений старт: книга вихователя : методичний посібник (Т.О. Піроженко, наук. ред., О.Ю. Хартман, заг. ред.). В 3 частинах. Ч. 1 Київ: Українська академія дитинства.

Гавриш, Н.В., Панасюк, Т.В., Піроженко, Т.О., Рогозянський, О.С., Хартман, О.Ю., \& Шевчук, А.С. (2017b). Освітня програма "Впевнений старт» для дітей старшого дошкільного віку (Т.О. Піроженко, заг. наук. ред.). Київ: ТОВ «Українська академія дитинства». 
Климець, К.В., \& Піроженко, Т.О. (2016). Рухова активність та психічне благополуччя дитини старшого дошкільного віку : навчально-методичний посібник. Київ: Видавничий дім «Слово».

Парціальна програма з розвитку соціальних навичок есрективної взаємодії дітей від 4 до 6-7 років «Вчимося жити разом». (2016). Представництво Дитячого фонду ООН (ЮНІСЕФ) в Україні. Київ: Видавництво «Алатон». https://mon.gov.ua/storage/ app/media/doshkilna/programi/1.pdf

Піроженко, Т.О., \& Хартман, О.Ю. (2014). Виховуємо дитину - зростаємо як батьки : навчальнометодичний посібник. Тернопіль: Мандрівець.

Піроженко, Т.О., Ладивір, С.О, Карасьова, К.В. та ін. (2014a). Дитина у сучасному соціопросторі : навчальний посібник (Т.О. Піроженко, ред.). Київ. Кіровоград: Імекс-ЛТД.

Піроженко, Т.О., Ладивір, С.О, Карасьова, К.В. та ін. (2014b). Сучасні діти - відображення цінностей дорослого світу : методичні рекомендації (Т.О. Піроженко, ред.). Київ: Кіровоград: Імекс-ЛТД.
Піроженко, Т.О., Ладивір, С.О., Соловйова, Л.І. та ін. (2016). Компас у світі ціннісних орієнтацій дошкільника : навчальний посібник. Київ: Видавничий дім «Слово».

Піроженко, Т.О., Соловйова, Л.І. та ін. (2016). Ціннісні орієнтації дитини у дорослому світі : навчальнометодичний посібник. Київ: Видавничий дім «Слово».

Піроженко, Т.О., Соловйова, Л.І., \& Хартман, О.Ю. (2017). Соціально значущі цінності в життедіяльності майбутнього школяра : методичні рекомендації (Т.О. Піроженко, ред.). Київ: Видавничий дім «Слово».

Піроженко, Т.О., Соловйова, Л.І., Карабаєва, І.І. та ін. (2017). Реалії вибору сочіально значущих цінностей : посібник (Т.О. Піроженко, ред.). Київ: Видавничий дім «Слово».

Піроженко, Т.О., Хартман, О.Ю., Палієнко, К.В., \& Павленко, М.В. (2016). Методичний посібник до парціальної програми з розвитку соціальних навичок ефективної взаємодії дітей віком від 4-х до 6-7 років «Вчимося жити разом». Київ: Алатон.

\section{FORMATION OF VALUE ORIENTATIONS OF CHILDREN OF PRESCHOOL AND PRIMARY SCHOOL AGE IN GAME AND EDUCATIONAL ACTIVITY IN THE EDUCATIONAL SYSTEM “JOYFULNESS OF DEVELOPMENT" Scientific report at the meeting of the Presidium of the National Academy of Educational Sciences of Ukraine, February 20, 2020}

Tamara Pirozhenko

DSc in Psychology, Professor, Corresponding Member of NAES of Ukraine, Head of the Laboratory of Preschooler Psychology, G.S. Kostiuk Institute of Psychology of the National Academy of Educational Sciences, Kyiv, Ukraine Olena Khartman

PhD in Psychology, Senior Researcher of the Laboratory of Preschooler Psychology, G.S. Kostiuk Institute of Psychology of the National Academy of Educational Sciences, Kyiv, Ukraine

Abstract. The implementation of the technology of psychological and pedagogical design of interaction between an adult and a child "Joyfulness of development" within the research "Psychological and pedagogical conditions of forming the value orientations of children in game and educational activity of the educational system "Joyfulness of development" is enlightened in the report. The research conceptual ideas and tasks are described. The central and main idea in implementing the educational system "Joyfulness of development" is the statement that the life organization of play and educational activity of a child from 2 to 12 years within the thematic cycle allows to realize the psychological and pedagogical conditions of freedom and acceptance of the child values. These values act as a mechanism of activity, creative activity, self-realization and self-presentation of personality. Allocated external (socialpedagogical) and internal (psychological) factors of influence on the process of acceptance of socially significant values by the child are distinguished. The current results of the research are presented. The high degree of uncertainty, variability, variability of developmental conditions and the need to determine the balance of methodical techniques, methods, forms of work with children of preschool and primary school age are emphasized.

Keywords: value orientations; educational system "Joyfulness of development"; thematic cycle; psychology of child development; subculture of childhood. 